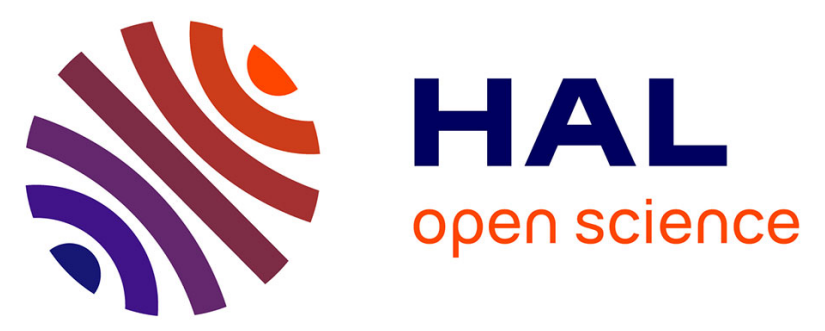

\title{
Evaluation and characterisation of a collection of wild Spanish populations of the genera Elymus and Thinopyrum using morphological and agronomical traits Rosa Nieto-López, Carlos Casanova, Consuelo Soler
}

\section{To cite this version:}

Rosa Nieto-López, Carlos Casanova, Consuelo Soler. Evaluation and characterisation of a collection of wild Spanish populations of the genera Elymus and Thinopyrum using morphological and agronomical traits. Agronomie, 2000, 20 (1), pp.111-122. 10.1051/agro:2000111 . hal-00885997

\section{HAL Id: hal-00885997 https://hal.science/hal-00885997}

Submitted on 1 Jan 2000

HAL is a multi-disciplinary open access archive for the deposit and dissemination of scientific research documents, whether they are published or not. The documents may come from teaching and research institutions in France or abroad, or from public or private research centers.
L'archive ouverte pluridisciplinaire HAL, est destinée au dépôt et à la diffusion de documents scientifiques de niveau recherche, publiés ou non, émanant des établissements d'enseignement et de recherche français ou étrangers, des laboratoires publics ou privés. 


\title{
Evaluation and characterisation of a collection of wild Spanish populations of the genera Elymus and Thinopyrum using morphological and agronomical traits
}

\author{
Rosa Marìa Nieto-LóPez, Carlos CASAnova, Consuelo Soler* \\ Department of Plant Breeding and Biotechnology, I.N.I.A \\ La Canaleja, P.O. Box 1045, 28800 Alcalá de Henares (Madrid), Spain
}

(Received 30 August 1999; accepted 1 December 1999)

\begin{abstract}
Quantification of the variability in wild species is a necessary step before determining their possible future use in plant breeding. A collection of 29 wild Spanish populations of the genera Elymus and Thinopyrum was characterised using 22 morphological and agronomical characteristics. Field studies were performed over two years, 1994 and 1995. Frequencies were calculated for qualitative and quantitative traits. Pearson's product-moment correlation coefficient was used to analyse inter-population variation using frequency data. Means and coefficients of variation were calculated for quantitative characteristics. Analysis of variance was performed for each species to study differences between intra- and inter-populational variability. Similar degrees of variability were observed between quantitative and qualitative traits in all the species studied (T. junceum, T. junceiforme, E. caninus and E. hispanicus). Differences in variability were found at the level of species and population. The relationships between these differences and biological and environmental factors are discussed.
\end{abstract}

\section{Elymus / Thinopyrum / variability / evaluation / characterisation}

Résumé - Évaluation et caractérisation d'une collection de populations sauvages espagnoles des genres Elymus et Thinopyrum, sur la base de caractères morphologiques et agronomiques. La quantification de la variabilité des espèces sauvages est un pas nécessaire avant leur possible utilisation dans l'amélioration végétale. Une collection de 29 populations sauvages espagnoles des genres Elymus et Thinopyrum a été caractérisée à l'aide de 22 caractères morphologiques et agronomiques. Les études en champ ont été réalisées pendant deux années, 1994 et 1995 . Les fréquences ont été calculées pour les caractères qualitatifs et quantitatifs. Le coefficient de la correlation produit-moment de Pearson a

Communicated by Nicolas Jouve (Madrid, Spain)

*Correspondence and reprints

llinares@inia.es 
été utilisé pour analyser la variation interpopulationnelle, à partir des données des fréquences. Les moyennes et les coefficients de variation ont été calculés pour les caractéristiques quantitatives. L'analyse de la variance dans chaque espèce a permis d'étudier les différences entre la variabilité intra et interpopulationnelle. Des niveaux semblables de variabilité ont été observés entre caractères quantitatifs et qualitatifs dans toutes les espèces etudiées. Des différences de variabilité ont été trouvées au niveau des espèces et de la population. Les relations entre ces différences et des facteurs biologiques et de l'environnement sont discutés.

Elymus / Thinopyrum / variabilité / évaluation / caractérisation

\section{Introduction}

The aim of plant cultivation is to increase cultivar production whilst maintaining genetic variability. For most traits it is sufficient to ensure variability in the primary "gene pool", but it is often necessary to make crosses with more distant species [2]. The genus Thinopyrum, belonging to the perennial tribe Triticeae, has traditionally been of interest to wheat breeders since many of the species in this group hybridise with wheat and are resistent to disease, drought and salinity. Thinopyrum consists of three species complexes: $T$. junceum, T. elongatum and T. intermedium [3]. The species included in the complex T. junceum found in Spain are T. junceum (L.) Löve, with a distribution around the European and Asian Mediterranean seashore, and Thinopyrum junceiforme (Löve \& Löve), which is found around Baltic and Atlantic coasts.

According to the genomic classification of Löve [9], Elymus is the largest genus of the tribe Triticeae, with more than 150 perennial species. It is also the most widespread, growing in Europe, Asia, North America, South America, New Zealand and Australia [3]. Many Elymus species have good fodder qualities, are highly productive in favourable conditions, and are resistant to different diseases [3, 14, 18]. According to the genomic classification of Löve [9], two representatives of this genus are found in Spain: E. caninus (L.) Linnaeus and E. panormitanus (Parl.) Tzvelev. E. caninus grows in the Cantabrian Range, the Pyrenees, Galicia (northwestern Spain) and the Central and Iberian Ranges (central Spain). Its southern limit lies at 37 north. E. panormitanus
(Parl.) Tzvelev is found in the southern part of the Iberian Peninsula [10]. In 1986, Talavera [16], using morphological characteristics, considered the Spanish variant of $E$. panormitanus to be a distinct species and named it E. hispanicus. In an earlier, molecular study made by the present authors (unpublished), the results suggested that E. hispanicus should be viewed as a species in its own right.

The description of agronomically useful characteristics is an important pre-requisite for effective and efficient utilisation of germplasm collections in breeding programmes [4]. The objectives of this work were to evaluate, characterise and maintain 29 wild Spanish populations of the genera Elymus and Thinopyrum, analyse their inter- and intrapopulational phenotypic variations, detect specific characteristics of interest and determine the relationships between them and environmental factors.

\section{Materials and methods}

\subsection{Plant material}

The plant material consisted of twenty-nine wild Spanish populations of the genera Elymus and Thinopyrum (Tab. I). This material forms part of the living collection of wild relatives of cultivated Triticeae obtained from natural environments [15] and maintained at the Plant Breeding and Biotechnology Department of the I.N.I.A (La Canaleja, Madrid, Spain). In order to maintain the original structure of the natural population, each sample was formed by approximately 100 ears collected at random from each population according to Hawkes [7]. 
In the autumn, seeds were germinated on filter paper and transferred to small containers in the greenhouse. Seedlings were planted in the field at the end of winter. This process was performed from 1993 to 1994 and from 1994 to 1995 at the La Canaleja Research Station, I.N.I.A., Alcalá de Henares (Spain).

A total of 30 plants were scored from each population. Populations were divided into three blocks. Each block contained 14 plants from each popula- tion arranged in a row. Observations were made on the 10 central plants. Separation between plants within a row and between rows was $50 \mathrm{~cm}$. Preplanting fertilisation consisted of $300 \mathrm{~kg} / \mathrm{Ha}$ of $\mathrm{N}: \mathrm{P}: \mathrm{K}$ in the ratio of 8:24:8. After planting, a further $150 \mathrm{~kg} / \mathrm{Ha}$ of ammonium nitrate (26\%) was applied. Plants were irrigated once after planting and then every 15 days during the months of June and July.

Table I. Populations (PO.) of T. junceum, T. junceiforme, E. caninus and E. hispanicus analysed. The geographical origin (by province) in Spain, altitude (meters), latitude, longitude, temperature $\left(\mathrm{T},{ }^{\circ} \mathrm{C}\right)$ and pluviometry $(\mathrm{P}, \mathrm{mm})$ are indicated.

\begin{tabular}{|c|c|c|c|c|c|c|}
\hline PO. & Province & Altitude & Latitude & Longitude & $\mathrm{T}\left({ }^{\circ} \mathrm{C}\right)$ & $\mathrm{P}(\mathrm{mm})$ \\
\hline \multicolumn{7}{|c|}{ T. junceum } \\
\hline 0036 & Almeria & 3 & $36^{\circ} 50^{\prime} 15^{\prime \prime} \mathrm{N}$ & $02^{\circ} 21^{\prime} 00^{\prime \prime} \mathrm{W}$ & 17.9 & 231 \\
\hline 0045 & Murcia & 2 & $37^{\circ} 43^{\prime} 45^{\prime \prime} \mathrm{N}$ & $00^{\circ} 44^{\prime} 10^{\prime \prime} \mathrm{W}$ & 17.3 & 231 \\
\hline 0102 & Tarragona & 1 & $41^{\circ} 07^{\prime} 50^{\prime \prime} \mathrm{N}$ & $01^{\circ} 36^{\prime} 15^{\prime \prime} \mathrm{W}$ & 15.8 & 478 \\
\hline 0103 & Tarragona & 2 & $41^{\circ} 08^{\prime} 05^{\prime \prime} \mathrm{N}$ & $01^{\circ} 37^{\prime} 00^{\prime \prime} \mathrm{W}$ & 15.8 & 478 \\
\hline 0126 & Valencia & 2 & $39^{\circ} 29^{\prime} 35^{\prime \prime} \mathrm{N}$ & $00^{\circ} 19^{\prime} 20^{\prime \prime} \mathrm{W}$ & 16.9 & 422 \\
\hline 0153 & Tarragona & 1 & $40^{\circ} 35^{\prime} 30^{\prime \prime} \mathrm{N}$ & $00^{\circ} 42^{\prime} 40^{\prime \prime} \mathrm{E}$ & 16.8 & 576 \\
\hline 0525 & Granada & 3 & $36^{\circ} 42^{\prime} 15^{\prime \prime} \mathrm{N}$ & $03^{\circ} 27^{\prime} 35^{\prime \prime} \mathrm{W}$ & 18.0 & 455 \\
\hline 0526 & Granada & 3 & $36^{\circ} 43^{\prime} 10^{\prime \prime} \mathrm{N}$ & $03^{\circ} 32^{\prime} 50^{\prime \prime} \mathrm{W}$ & 18.0 & 455 \\
\hline 0527 & Malaga & 2 & $36^{\circ} 27^{\prime} 25^{\prime \prime} \mathrm{N}$ & $05^{\circ} 02^{\prime} 60^{\prime \prime} \mathrm{W}$ & 18.6 & 648 \\
\hline 1042 & Valencia & 2 & $39^{\circ} 05^{\prime} 00^{\prime \prime} \mathrm{N}$ & $00^{\circ} 12^{\prime} 45^{\prime \prime} \mathrm{W}$ & 16.9 & 422 \\
\hline 1043 & Valencia & 1 & $39^{\circ} 24^{\prime} 10^{\prime \prime} \mathrm{N}$ & $00^{\circ} 19^{\prime} 40^{\prime \prime} \mathrm{W}$ & 16.9 & 422 \\
\hline 1044 & Barcelona & 1 & $41^{\circ} 36^{\prime} 10^{\prime \prime} \mathrm{N}$ & $02^{\circ} 37^{\prime} 50^{\prime \prime} \mathrm{E}$ & 16.4 & 593 \\
\hline \multicolumn{7}{|c|}{ T. junceiforme } \\
\hline 528 & Cádiz & 2 & $36^{\circ} 00^{\prime} 45^{\prime \prime} \mathrm{N}$ & $05^{\circ} 36^{\prime} 30^{\prime \prime} \mathrm{W}$ & 17.2 & 749 \\
\hline 530 & Cádiz & 1 & $36^{\circ} 32^{\prime} 00^{\prime \prime} \mathrm{N}$ & $06^{\circ} 14^{\prime} 15^{\prime \prime} \mathrm{W}$ & 16.7 & 546 \\
\hline \multicolumn{7}{|c|}{ E. caninus } \\
\hline 0053 & Oviedo & 1370 & $42^{\circ} 59^{\prime} 45^{\prime \prime} \mathrm{N}$ & $05^{\circ} 45^{\prime} 50^{\prime \prime} \mathrm{W}$ & 8.00 & 1140 \\
\hline 0484 & Granada & 1450 & $37^{\circ} 58^{\prime} 50^{\prime \prime} \mathrm{N}$ & $02^{\circ} 32^{\prime} 00^{\prime \prime} \mathrm{W}$ & 10.10 & 1166 \\
\hline 0513 & Madrid & 1400 & $40^{\circ} 51^{\prime} 50^{\prime \prime} \mathrm{N}$ & $03^{\circ} 45^{\prime} 50^{\prime \prime} \mathrm{W}$ & 10.10 & 895 \\
\hline 0514 & Madrid & 1300 & $40^{\circ} 53^{\prime} 15^{\prime \prime} \mathrm{N}$ & $03^{\circ} 46^{\prime} 45^{\prime \prime} \mathrm{W}$ & 10.10 & 895 \\
\hline 0515 & Segovia & 950 & $41^{\circ} 17^{\prime} 25^{\prime \prime} \mathrm{W}$ & $03^{\circ} 42^{\prime} 15^{\prime \prime} \mathrm{N}$ & 11.40 & 468 \\
\hline 1054 & Huesca & 1400 & $42^{\circ} 38^{\prime} 30^{\prime \prime} \mathrm{N}$ & $00^{\circ} 33^{\prime} 40^{\prime \prime} \mathrm{E}$ & 9.90 & 1152 \\
\hline 1058 & Huesca & 700 & $42^{\circ} 26^{\prime} 30^{\prime \prime} \mathrm{N}$ & $00^{\circ} 23^{\prime} 15^{\prime \prime} \mathrm{E}$ & 11.0 & 1158 \\
\hline 1061 & Huesca & 1050 & $42^{\circ} 38^{\prime} 20^{\prime \prime} \mathrm{N}$ & $00^{\circ} 13^{\prime} 00^{\prime \prime} \mathrm{E}$ & 9.90 & 1152 \\
\hline 1071 & Andorra & 760 & $42^{\circ} 36^{\prime} 20^{\prime \prime} \mathrm{N}$ & $00^{\circ} 06^{\prime} 45^{\prime \prime} \mathrm{W}$ & 10.60 & 793 \\
\hline 1091 & Andorra & 1400 & $42^{\circ} 30^{\prime} 00^{\prime \prime} \mathrm{N}$ & $01^{\circ} 30^{\prime} 50^{\prime \prime} \mathrm{E}$ & 9.10 & 1321 \\
\hline \multicolumn{7}{|c|}{ E. hispanicus } \\
\hline 475 & Jaén & 1280 & $37^{\circ} 54^{\prime} 45^{\prime \prime} \mathrm{N}$ & $02^{\circ} 55^{\prime} 30^{\prime \prime} \mathrm{W}$ & 15.70 & 772 \\
\hline 485 & Granada & 1820 & $36^{\circ} 57^{\prime} 34^{\prime \prime} \mathrm{N}$ & $02^{\circ} 42^{\prime} 53^{\prime \prime} \mathrm{W}$ & 17.70 & 360 \\
\hline 488 & Granada & 1210 & $37^{\circ} 18^{\prime} 10^{\prime \prime} \mathrm{N}$ & $03^{\circ} 26^{\prime} 45^{\prime \prime} \mathrm{W}$ & 13.00 & 740 \\
\hline 489 & Granada & 1430 & $37^{\circ} 08^{\prime} 00^{\prime \prime} \mathrm{N}$ & $03^{\circ} 24^{\prime} 00^{\prime \prime} \mathrm{W}$ & 13.00 & 740 \\
\hline 523 & Granada & 1200 & $37^{\circ} 00^{\prime} 25^{\prime \prime} \mathrm{N}$ & $04^{\circ} 12^{\prime} 35^{\prime \prime} \mathrm{W}$ & 16.90 & 524 \\
\hline
\end{tabular}




\section{2 . Characteristics examined}

The selection of morphological traits for evaluation was based on the descriptions made by different authors of the genera Elymus and Thinopyrum $[1,5,8,10,13]$. Agronomical characteristics of interest, such as days to heading, days to maturity, and seed production related traits were also included the study. During 1993-1994 the following traits were scored: (1) growth habit of young plants [1 erect to 3 prostrate], (2) stem pubescence of young plants [1 none to 3 pubescent], (3) stem colour [1 green to 3 purple], (4) leaf surface pubescence [1 none to 2 pubescent], (5) auricle colour at heading [ 1 green to 2 purple], (6) leaf texture [ 1 smooth to 2 rough], (7) kernel type [1 naked to 3 covered], (8) growth habit at maturity [ 1 erect to 5 prostrate], (9) flag leaf area [length $\times$ width $\times 0.70$ [10]], (10) plant height $(\mathrm{cm}),(11)$ spike length $(\mathrm{mm}),(12)$ rachis length (mm), (13) number of spikelets per spike, (14) spike density ( $\mathrm{mm}$ per rachis internode), (15) spikelet width (mm), (16) glume length (mm), (17) awn length (mm), (18) lemma length (mm), (19) number of kernels per spike, (20) fertility $[(\mathrm{K} \times 100) /(\mathrm{S}-1) \times 2, \mathrm{~K}$ being the number of kernels, and $\mathrm{S}$ the number of spikelets], (21) heading date (days after $31 \mathrm{March}$ ), and (22) maturity date (days after 31 March).

During 1994/5, only the traits numbered from 10 to 20 were scored.

\subsection{Statistical analyses}

Frequencies were calculated for each qualitative trait in each population and species. Analysis of variance, averages and coefficient of variation for quantitative traits were calculated with the STATGRAPHICS PLUS programme (Manugistics Inc. and Statistical Graphics Corporation). All quantitative and qualitative values of the year 1993-94, except for spike density and fertility (which are combinations of other values), were used to construct a matrix of population frequencies. In order to transform the values of quantitative traits to frequencies, equal classes were established with an approximate interval of twice the standard devia- tion of the specific character. The matrix of frequencies was used to estimate the similarity between populations using Pearson's productmoment correlation coefficient [11]. The NTSYS, Numerical Taxonomy System for PCs, package was used in this analysis [12].

\section{Results}

Differences were found in the germination and seed production rates of the different genera studied. In general, populations of Thinopyrum had lower germination rates than those of Elymus.

\subsection{Qualitative traits}

Frequencies per species for each qualitative character were calculated (Tab. II). The traits for growth characteristic and leaf surface pubescence were found to be different for each genus. Most young plants of Thinopyrum were erect or semierect. In contrast, most plants of Elymus were prostrate or semi-erect. At maturity, the frequency of prostrate and semi-erect plants increased in Thinopyrum, while most Elymus plants remained erect or slightly prostrate. Thinopyrum showed no variability in leaf surface pubescence - all plant samples were pubescent. However Elymus did show variability for this character.

At the level of species, E. hispanicus showed the least variability; only 4 of the 8 traits analysed were found to be variable. The most and least variable populations were 0523 and 0485 with 4 and 2 variable traits respectively (Tab. III).

E. caninus and $T$. junceum were variable for a larger number of traits, each population having a different level of variability. Populations 0515 and 0053 of E. caninus were polymorphic for 6 traits and one trait respectively. In T. junceum, populations 1043 and 1044 showed variability for 5 traits while populations 0102 and 0526 showed variability for 2 traits (Tab. III).

Populations of $T$. junceiforme showed similar traits to those of $T$. junceum. The most obvious 
Table II. Frequencies (\%) for each class for qualitatively scored characters in each species.

\begin{tabular}{|c|c|c|c|c|c|}
\hline Character & Class & T. junceum & T. junceiforme & E. caninus & E. hispanicus \\
\hline $\begin{array}{l}\text { Growth habit } \\
\text { of young plants }\end{array}$ & $\begin{array}{c}1 \text { erect } \\
2 \\
3 \text { postrate }\end{array}$ & $\begin{array}{c}81 \\
18 \\
1\end{array}$ & $\begin{array}{c}93 \\
7 \\
0\end{array}$ & $\begin{array}{c}0 \\
16 \\
84\end{array}$ & $\begin{array}{l}4 \\
81 \\
15\end{array}$ \\
\hline $\begin{array}{l}\text { Stem pubescence } \\
\text { of young plants }\end{array}$ & $\begin{array}{c}1 \text { none } \\
2 \\
3 \text { pubescent }\end{array}$ & $\begin{array}{c}78 \\
2 \\
19\end{array}$ & $\begin{array}{c}100 \\
0 \\
0\end{array}$ & $\begin{array}{c}60 \\
3 \\
37\end{array}$ & $\begin{array}{c}100 \\
0 \\
0\end{array}$ \\
\hline $\begin{array}{l}\text { Stem colour } \\
\text { of young plants }\end{array}$ & $\begin{array}{c}1 \text { green } \\
2 \\
3 \text { purple }\end{array}$ & $\begin{array}{c}3 \\
94 \\
3\end{array}$ & $\begin{array}{c}0 \\
77 \\
23\end{array}$ & $\begin{array}{c}4 \\
51 \\
45\end{array}$ & $\begin{array}{c}18 \\
82 \\
0\end{array}$ \\
\hline $\begin{array}{l}\text { Leaf surface } \\
\text { pubescence }\end{array}$ & $\begin{array}{c}1 \text { none } \\
2 \text { pubescent }\end{array}$ & $\begin{array}{c}0 \\
100\end{array}$ & $\begin{array}{c}0 \\
100\end{array}$ & $\begin{array}{l}79 \\
21\end{array}$ & $\begin{array}{l}50 \\
50\end{array}$ \\
\hline $\begin{array}{l}\text { Auricle colour at } \\
\text { heading }\end{array}$ & $\begin{array}{l}1 \text { green } \\
2 \text { purple }\end{array}$ & $\begin{array}{c}94 \\
6\end{array}$ & $\begin{array}{l}56 \\
44\end{array}$ & $\begin{array}{l}87 \\
13\end{array}$ & $\begin{array}{c}100 \\
0\end{array}$ \\
\hline Leaf texture & $\begin{array}{l}1 \text { smooth } \\
2 \text { rough }\end{array}$ & $\begin{array}{c}100 \\
0\end{array}$ & $\begin{array}{c}100 \\
0\end{array}$ & $\begin{array}{c}0 \\
100\end{array}$ & $\begin{array}{c}0 \\
100\end{array}$ \\
\hline Kernel type & $\begin{array}{c}1 \text { naked } \\
2 \\
3 \text { covered }\end{array}$ & $\begin{array}{c}2 \\
0 \\
98\end{array}$ & $\begin{array}{l}11 \\
15 \\
74\end{array}$ & $\begin{array}{c}0 \\
5 \\
95\end{array}$ & $\begin{array}{c}1 \\
0 \\
99\end{array}$ \\
\hline $\begin{array}{l}\text { Growth habit } \\
\text { at maturity }\end{array}$ & $\begin{array}{c}1 \text { erect } \\
2 \\
3 \\
4 \\
5 \text { prostrate }\end{array}$ & $\begin{array}{c}22 \\
38 \\
35 \\
4 \\
1\end{array}$ & $\begin{array}{c}0 \\
11 \\
33 \\
29 \\
27\end{array}$ & $\begin{array}{c}8 \\
92 \\
0 \\
0 \\
0\end{array}$ & $\begin{array}{c}0 \\
100 \\
0 \\
0 \\
0\end{array}$ \\
\hline
\end{tabular}

differences were that $T$. junceiforme had a higher frequency of plants with purple auricles, naked kernels and greater prostrate growth characteristic (Tab. II).

\subsection{Quantitative traits}

For two years, quantitative variation was analysed statistically for each species (Tab. IV) and population (Tabs. V and VI). At the genus level, the Thinopyrum species analysed either lacked awns or had only rudimentary structures. Thinopyrum spikelets appeared wider and the lemmas were longer than in Elymus. In contrast, the
Elymus species showed wider leaves, more spikelets per spike, and higher spike densities than those of Thinopyrum.

At the species level, the annual means varied according to certain tendencies. In $T$. junceum, the means of the variables related to plant vigour, such as, height, length of spikes and number of spikelets, decreased in the second year, while the variables related to spike productivity, such as spikelet width, number of kernels and fertility, increased. When comparing T. junceiforme with $T$. junceum it was observed that $T$. junceiforme showed smaller means for most traits, but the tendencies for the second year were similar to those of T. junceum, e.g., means related to vigour decreased 
Table III. Prescence (1) and absence (0) of variability in each population of the four species analysed for each character.

\begin{tabular}{|c|c|c|c|c|c|c|c|c|}
\hline & $\begin{array}{l}\text { Growth habit } \\
\text { of young } \\
\text { plants }\end{array}$ & $\begin{array}{c}\text { Stem pubescence } \\
\text { of young } \\
\text { plants }\end{array}$ & $\begin{array}{l}\text { Stem color } \\
\text { of young } \\
\text { plants }\end{array}$ & $\begin{array}{c}\text { Leaf } \\
\text { surface } \\
\text { pubescence }\end{array}$ & $\begin{array}{c}\text { Auricle } \\
\text { colour } \\
\text { at heading }\end{array}$ & $\begin{array}{l}\text { Kernel } \\
\text { type }\end{array}$ & $\begin{array}{l}\text { Growth } \\
\text { habit } \\
\text { at maturity }\end{array}$ & Total \\
\hline \multicolumn{9}{|c|}{ T. јипсеит } \\
\hline 0036 & 1 & 0 & 1 & 0 & 0 & 0 & 1 & 3 \\
\hline 0045 & 1 & 0 & 1 & 0 & 0 & 1 & 1 & 4 \\
\hline 0102 & 0 & 0 & 0 & 0 & 1 & 0 & 1 & 2 \\
\hline 0103 & 1 & 0 & 0 & 0 & 1 & 1 & 1 & 4 \\
\hline 0126 & 1 & 1 & 1 & 0 & 0 & 0 & 1 & 4 \\
\hline 0153 & 0 & 1 & 1 & 0 & 1 & 0 & 1 & 4 \\
\hline 0525 & 1 & 1 & 10 & 0 & 0 & 0 & 1 & 4 \\
\hline 0526 & 0 & 1 & 0 & 0 & 0 & 0 & 1 & 2 \\
\hline 0527 & 1 & 1 & 0 & 0 & 1 & 0 & 1 & 4 \\
\hline 1042 & 1 & 0 & 0 & 0 & 1 & 1 & 1 & 4 \\
\hline 1043 & 1 & 1 & 1 & 0 & 1 & 0 & 1 & 5 \\
\hline 1044 & 1 & 0 & 1 & 0 & 1 & 1 & 1 & 5 \\
\hline Total & 9 & 6 & 7 & 0 & 7 & 4 & 12 & \\
\hline \multicolumn{9}{|c|}{ T. junceiforme } \\
\hline 0528 & 1 & 0 & 1 & 0 & 1 & 1 & 1 & 5 \\
\hline 0530 & 0 & 0 & 1 & 0 & 1 & 1 & 1 & 4 \\
\hline Total & 1 & 0 & 2 & 0 & 2 & 2 & 2 & \\
\hline \multicolumn{9}{|c|}{ E. caninus } \\
\hline 0053 & 1 & 0 & 0 & 0 & 0 & 0 & 0 & 1 \\
\hline 0484 & 1 & 1 & 1 & 0 & 1 & 0 & 0 & 4 \\
\hline 0513 & 1 & 0 & 1 & 0 & 1 & 0 & 0 & 3 \\
\hline 0514 & 1 & 1 & 1 & 0 & 0 & 1 & 1 & 5 \\
\hline 0515 & 1 & 1 & 1 & 0 & 1 & 1 & 1 & 6 \\
\hline 1054 & 1 & 0 & 1 & 1 & 1 & 1 & 0 & 5 \\
\hline 1058 & 1 & 0 & 1 & 1 & 1 & 1 & 0 & 5 \\
\hline 1061 & 1 & 0 & 1 & 1 & 1 & 0 & 1 & 5 \\
\hline 1071 & 1 & 0 & 1 & 0 & 0 & 1 & 1 & 4 \\
\hline 1091 & 1 & 0 & 1 & 1 & 0 & 0 & 1 & 4 \\
\hline Total & 10 & 3 & 9 & 4 & 6 & 5 & 5 & \\
\hline \multicolumn{9}{|c|}{ E. hispanicus } \\
\hline 0475 & 1 & 0 & 1 & 1 & 0 & 0 & 0 & 3 \\
\hline 0485 & 1 & 0 & 0 & 1 & 0 & 0 & 0 & 2 \\
\hline 0488 & 1 & 0 & 1 & 1 & 0 & 0 & 0 & 3 \\
\hline 0489 & 1 & 0 & 1 & 1 & 0 & 0 & 0 & 3 \\
\hline 0523 & 1 & 0 & 1 & 1 & 0 & 1 & 0 & 4 \\
\hline Total & 5 & 0 & 4 & 5 & 0 & 1 & 0 & \\
\hline
\end{tabular}

and means related to spike productivity increased. The means of plant height, spike length, spikelet length, glume length, spikelet width, lemma length, kernel number and fertility of $E$. caninus increased significantly $(\mathrm{P}<0.01)$ during the second year.

The species E. hispanicus seemed to have more vigour than $E$. caninus, but its spikes were less dense and the glumes and lemmas were bigger than those of E. caninus. Tendencies of this species during the second year were more similar to those of Thinopyrum than to those of E. caninus.

Although the average values per species and population varied annually, in $T$. junceum it was observed that some populations behaved similarly 
Table IV. Means for quantitative traits for two years and four species.

\begin{tabular}{|c|c|c|c|c|c|c|c|c|}
\hline \multirow[t]{2}{*}{ Trait } & \multicolumn{2}{|c|}{ T. junceum } & \multicolumn{2}{|c|}{ T. junceiforme } & \multicolumn{2}{|c|}{ E. caninus } & \multicolumn{2}{|c|}{ E. hispanicus } \\
\hline & 94 & 95 & 94 & 95 & 94 & 95 & 94 & 95 \\
\hline Flag leaf area $\left(\mathrm{cm}^{2}\right)$ & 6.2 & & 5.6 & & 12.3 & & 14.1 & \\
\hline Plant height $(\mathrm{cm})$ & $76.3 * *$ & 66.2 & 59.3 & 58.3 & $73.3 * *$ & 81.6 & $90 * *$ & 86.4 \\
\hline Spike length (mm) & 230.4 & 224.5 & 155.7 & 148.3 & $198.9 * *$ & 209.6 & $219.5 * *$ & 202.9 \\
\hline Rachis length (mm) & 206.9 & 201.2 & 132.4 & 124.7 & $178.8 * *$ & 200.3 & $202.5^{* *}$ & 185.5 \\
\hline $\begin{array}{l}\text { Number of spikelets } \\
\text { per spike }\end{array}$ & 9.7 & 9.6 & 9.7 & 8.8 & 24.6 & 24.1 & $17.2^{*}$ & 15.9 \\
\hline $\begin{array}{l}\text { Spike density } \\
\text { (mm/internode) }\end{array}$ & 4.4 & 4.6 & 6.6 & 6.2 & $13.5 * *$ & 11.6 & 8 & 8 \\
\hline Spikelet width (mm) & $6.4 * *$ & 8.8 & $6.4 * *$ & 7.8 & $3 * *$ & 3.1 & $3.1 * *$ & 3.9 \\
\hline Glume length (mm) & 15.9 & 15.7 & $12.6^{* *}$ & 11.6 & $9.3 * *$ & 9.9 & $124 * *$ & 15.2 \\
\hline Awn length (mm) & & & & & 10.5 & 10.1 & $9.4 * *$ & 10.5 \\
\hline Lemma length (mm) & $15.4^{*}$ & 15.7 & 13.3 & 13.7 & $9.7 * *$ & 10.2 & 12.6 & 12.8 \\
\hline $\begin{array}{l}\text { Number of kernels } \\
\text { per spike }\end{array}$ & $9.9 * *$ & 24.1 & 5.9 & 6.4 & $5.6 * *$ & 55.4 & $9 * *$ & 35.5 \\
\hline Fertility & $58.1 * *$ & 141.5 & 32.6 & 39.2 & $11.9 * *$ & 115.9 & $28.8^{* *}$ & 121.3 \\
\hline $\begin{array}{l}\text { Heading date, } \\
\text { days after } 3 / 31\end{array}$ & 68.8 & 69.6 & $62.3 *$ & 65.8 & $78.4 * *$ & 81.2 & 58.3 & 57.4 \\
\hline $\begin{array}{l}\text { Maturity date, } \\
\text { days after } 3 / 31\end{array}$ & $110.0 * *$ & 103.0 & 106.5 & 105.9 & $110.1 * *$ & 106.7 & $94.03 * *$ & 88.9 \\
\hline
\end{tabular}

*, ** Means between years differ at $\mathrm{P}=0.05$ and 0.01 respectively.

over both years (Tab. V). Populations with higher values for plant height the first year - 0045 $(94.4 \mathrm{~cm})$ and $0153(93.7 \mathrm{~cm})$ - were also the tallest the second year $-0045(79.9 \mathrm{~cm})$ and 0153 $(76.3 \mathrm{~cm})$ - and populations with lower values for plant height the first year - $0525(66.6 \mathrm{~cm})$ and $0527(68.6 \mathrm{~cm})$ - were also the shortest the second year - $0525(60.0 \mathrm{~cm})$ and $0527(59.0 \mathrm{~cm})$. Population 1044 had bigger spikes and a greater number of spikelets for both years. Population 1043 had a higher number of kernels per spike over both years. Taking into account days to maturity and days to heading, population 1044 had the longest and population 527 the shortest cycle for both years.

The populations of E. caninus and E. hispanicus maintained extreme values both years only for characteristics such as awn length, days to heading, and days to maturity. In E. caninus, populations 0513 and 0484 had the largest and shortest cycles respectively for both years. The same occurred with populations of 0489 and 0523 of E. hispanicus (Tab. VI).

Phenotypic diversity of populations and species (Tab. VII) was studied using the coefficient of variation $(\mathrm{CV})$ which provides an estimate of variation among groups [19]. In the study of variability of quantitative characteristics, the density and fertility of the spikes was not used because they are combinations of other traits. The average $\mathrm{CV}$ per year and species was lower for E. hispanicus.

An analysis of variance was performed for each species to study inter-populational variability. Table VIII shows the F-value and significance of this analysis. Significant differences among populations show larger variability among populations than within them. For T. junceum, E. caninus and E. hispanicus, populations differed significantly (P $<0,01)$ for both years and for most of the characteristics studied. The two T. junceiforme popula- 
Table V. Means per year and population of Thinopyrum.

\begin{tabular}{|c|c|c|c|c|c|c|c|c|c|c|c|c|c|c|}
\hline Population & Year & $\begin{array}{l}\text { Plant } \\
\text { height } \\
(\mathrm{cm})\end{array}$ & $\begin{array}{l}\text { Spike } \\
\text { length } \\
(\mathrm{mm})\end{array}$ & $\begin{array}{l}\text { Rachis } \\
\text { length } \\
(\mathrm{mm})\end{array}$ & $\begin{array}{l}\text { Number of } \\
\text { spikelets } \\
\text { per spike }\end{array}$ & $\begin{array}{l}\text { Spikelet } \\
\text { width } \\
(\mathrm{mm})\end{array}$ & $\begin{array}{l}\text { Glume } \\
\text { length } \\
(\mathrm{mm})\end{array}$ & $\begin{array}{l}\text { Lemma } \\
\text { length } \\
(\mathrm{mm})\end{array}$ & $\begin{array}{c}\text { Number } \\
\text { kernels } \\
\text { per spike }\end{array}$ & $\begin{array}{c}\text { Days } \\
\text { to } \\
\text { heading }\end{array}$ & $\begin{array}{c}\text { Days } \\
\text { to } \\
\text { maturity }\end{array}$ & $\begin{array}{c}\text { Spike } \\
\text { Fertility }\end{array}$ & $\begin{array}{l}\text { Spike } \\
\text { density }\end{array}$ & $\begin{array}{l}\text { Flag leaf } \\
\text { area } \\
\left(\mathrm{cm}^{2}\right)\end{array}$ \\
\hline \multicolumn{15}{|c|}{ T. јипсеит } \\
\hline \multirow{2}{*}{0036} & 94 & 68.7 & 176.6 & 153.9 & 9.0 & 6.4 & 15.1 & 14.4 & 9.5 & 70.6 & 108.0 & 54.5 & 5.5 & 7.5 \\
\hline & 95 & 62.3 & 151.2 & 129.5 & 8.7 & 8.2 & 14.5 & 14.8 & 23.6 & 70.7 & 105.9 & 151.7 & 6.5 & \\
\hline \multirow[t]{2}{*}{0045} & 94 & 94.4 & 275.0 & 249.8 & 10.6 & 6.5 & 18.4 & 17.5 & 4.0 & 74.0 & 111.3 & 23.2 & 3.9 & 9.2 \\
\hline & 95 & 79.9 & 241.2 & 217.2 & 10.1 & 9.0 & 17.0 & 17.1 & 20.2 & 72.9 & 105.2 & 108.4 & 4.4 & \\
\hline \multirow[t]{2}{*}{0102} & 94 & 77.3 & 235.6 & 212.6 & 9.9 & 7.3 & 15.6 & 15.8 & 12.9 & 72.3 & 111.5 & 62.9 & 4.2 & 6.4 \\
\hline & 95 & 72.5 & 242.6 & 218.1 & 9.9 & 10.0 & 15.4 & 15.8 & 21.1 & 72.4 & 103.8 & 113.0 & 4.2 & \\
\hline \multirow[t]{2}{*}{0103} & 94 & 75.0 & 254.0 & 231.8 & 10.3 & 7.0 & 15.8 & 15.6 & 7.0 & 74.0 & 114.3 & 35.6 & 4.1 & 6.9 \\
\hline & 95 & 67.3 & 266.3 & 240.6 & 10.6 & 8.9 & 15.8 & 15.8 & 23.8 & 71.0 & 103.9 & 120.8 & 4.0 & \\
\hline \multirow[t]{2}{*}{0126} & 94 & 79.0 & 245.1 & 222.6 & 10.6 & 6.8 & 14.8 & 14.9 & 13.4 & 71.2 & 113.6 & 71.5 & 4.4 & 7.3 \\
\hline & 95 & 63.9 & 252.4 & 229.1 & 10.1 & 9.1 & 15.2 & 15.6 & 27.9 & 70.4 & 104.1 & 152.4 & 4.0 & \\
\hline \multirow[t]{2}{*}{0153} & 94 & 93.7 & 242.7 & 218.9 & 9.9 & 6.9 & 15.3 & 15.8 & 11.4 & 66.8 & 109.3 & 63.7 & 4.1 & 5.4 \\
\hline & 95 & 76.3 & 229.5 & 207.7 & 10.3 & 8.4 & 14.3 & 15.6 & 29.1 & 68.4 & 103.5 & 152.9 & 4.6 & \\
\hline \multirow[t]{2}{*}{0525} & 94 & 66.6 & 178.2 & 153.6 & 8.2 & 6.3 & 15.3 & 15.2 & 11.3 & 65.5 & 105.5 & 77.9 & 4.8 & 4.4 \\
\hline & 95 & 60.0 & 173.7 & 151.11 & 8.2 & 8.1 & 15.3 & 15.1 & 23.6 & 65.7 & 99.3 & 163.6 & 4.9 & \\
\hline \multirow[t]{2}{*}{0526} & 94 & 80.2 & 195.6 & 171.7 & 8.7 & 5.9 & 16.3 & 15.3 & 12.8 & 65.2 & 106.2 & 84.4 & 4.5 & 5.4 \\
\hline & 95 & 64.0 & 185.3 & 163.3 & 8.6 & 8.4 & 15.5 & 15.3 & 21.8 & 63.4 & 99.9 & 142.6 & 4.8 & \\
\hline \multirow[t]{2}{*}{0527} & 94 & 68.6 & 170.3 & 144.6 & 7.8 & 6.3 & 16.1 & 15.6 & 8.4 & 62.3 & 103.6 & 64.5 & 4.7 & 4.6 \\
\hline & 95 & 59.0 & 175.5 & 150.3 & 8.5 & 8.4 & 15.8 & 15.6 & 20.3 & 60.5 & 96.3 & 140.6 & 5.2 & \\
\hline \multirow[t]{2}{*}{1042} & 94 & 77.0 & 263.5 & 241.3 & 10.4 & 5.9 & 15.4 & 14.9 & 11.1 & 70.0 & 112.5 & 60.7 & 3.9 & 5.6 \\
\hline & 95 & 67.5 & 255.8 & 235.3 & 10.3 & 8.7 & 14.7 & 15.2 & 27.3 & 69.3 & 104.0 & 150.2 & 4.0 & \\
\hline \multirow[t]{2}{*}{1043} & 94 & 72.9 & 252.7 & 230.4 & 10.1 & 6.1 & 15.6 & 14.9 & 14.8 & 71.5 & 116.5 & 79.8 & 4.1 & 7.0 \\
\hline & 95 & 67.6 & 266.2 & 244.4 & 10.4 & 8.8 & 16.6 & 15.7 & 34.9 & 71.4 & 103.7 & 189.3 & 3.9 & \\
\hline \multirow[t]{2}{*}{1044} & 94 & 69.9 & 292.6 & 270.2 & 11.5 & 6.8 & 16.0 & 15.0 & 4.4 & 81.9 & 118.1 & 20.2 & 3.9 & 5.9 \\
\hline & 95 & 61.4 & 311.9 & 284.5 & 10.6 & 10.4 & 17.8 & 16.6 & 18.6 & 82.6 & 110.0 & 100.4 & 3.5 & \\
\hline \multicolumn{15}{|c|}{ T. junceiforme } \\
\hline \multirow[t]{2}{*}{0528} & 94 & 56.4 & 154.1 & 129.5 & 9.6 & 6.3 & 12.7 & 13.4 & 6.7 & 63.4 & 106.4 & 37.6 & 6.7 & 6.1 \\
\hline & 95 & 53.4 & 150.5 & 124.8 & 9.2 & 8.4 & 11.4 & 13.8 & 6.5 & 63.7 & 104.4 & 35.4 & 6.4 & \\
\hline \multirow[t]{2}{*}{0530} & 94 & 65.2 & 158.9 & 138.4 & 9.9 & 6.5 & 12.4 & 13.1 & 4.1 & 60.2 & 106.7 & 22.6 & 6.4 & 4.5 \\
\hline & 95 & 69.3 & 144.2 & 124.5 & 8.1 & 6.7 & 12.0 & 13.4 & 6.2 & 66.2 & 106.0 & 46.4 & 5.7 & \\
\hline
\end{tabular}

tions studied did not differ significantly with regard to most characteristics.

\subsection{Cluster analysis}

A matrix of frequencies was obtained using data for both quantitative and qualitative characteristics corresponding to 1994. This matrix was analysed using the Pearson product-moment coefficient. Cluster analysis was performed using the UPGMA method. Figure 1 shows the separation between the four species studied. The similarity index for separation between the genera Thinopyrum and Elymus was 0.28. Elymus species showed more variation between them (with a similarity index of 0.64) than species of Thinopyrum (with a similarity index of $0.75)$.

All the populations in this study appeared separated. Maximum separation between populations was $0.82,0.9,0.74$ and 0.85 for $T$. junceum, T. junceiforme, E. caninus and E. hispanicus respectively. 
Table VI. Means per year and population of Elymus.

\begin{tabular}{|c|c|c|c|c|c|c|c|c|c|c|c|c|c|c|c|}
\hline Population & Year & $\begin{array}{l}\text { Plant } \\
\text { height } \\
(\mathrm{cm})\end{array}$ & $\begin{array}{l}\text { Spike } \\
\text { length } \\
(\mathrm{mm})\end{array}$ & $\begin{array}{l}\text { Rachis } \\
\text { length } \\
(\mathrm{mm})\end{array}$ & $\begin{array}{l}\text { Number of } \\
\text { spikelets } \\
\text { per spike }\end{array}$ & $\begin{array}{l}\text { Spikelet } \\
\text { width } \\
(\mathrm{mm})\end{array}$ & $\begin{array}{l}\text { Glume } \\
\text { length } \\
(\mathrm{mm})\end{array}$ & $\begin{array}{l}\text { Awn } \\
\text { length } \\
(\mathrm{mm})\end{array}$ & $\begin{array}{l}\text { Lemma } \\
\text { length } \\
(\mathrm{mm})\end{array}$ & $\begin{array}{c}\text { Number } \\
\text { kernels } \\
\text { per spike }\end{array}$ & $\begin{array}{c}\text { Days } \\
\text { to } \\
\text { heading }\end{array}$ & $\begin{array}{c}\text { Days } \\
\text { to } \\
\text { maturity }\end{array}$ & $\begin{array}{c}\text { Spike } \\
\text { fertility }\end{array}$ & $\begin{array}{l}\text { Spike F } \\
\text { density }\end{array}$ & $\begin{array}{l}\text { lag leaf } \\
\text { area } \\
\left(\mathrm{cm}^{2}\right)\end{array}$ \\
\hline \multicolumn{16}{|l|}{ E. caninus } \\
\hline \multirow[t]{2}{*}{0053} & 94 & 70.4 & 201.8 & 175.6 & 20.7 & 3.0 & 9.2 & 10.6 & 10.2 & 2.9 & 76.7 & 111.6 & 7.2 & 11.5 & 12.9 \\
\hline & 95 & 93.5 & 211.2 & 201.0 & 21.9 & 3.0 & 9.9 & 10.2 & 10.3 & 42.6 & 74.7 & 99.5 & 101.0 & 10.4 & \\
\hline \multirow[t]{2}{*}{0484} & 94 & 89.1 & 229.7 & 217.7 & 23.4 & 3.0 & 9.6 & 12.1 & 11.2 & 6.8 & 66.7 & 95.6 & 14.7 & 10.2 & 10.2 \\
\hline & 95 & 85.0 & 187.4 & 178.9 & 19.6 & 3.0 & 8.8 & 6.9 & 10.1 & 29.9 & 70.8 & 96.3 & 76.9 & 10.5 & \\
\hline \multirow[t]{2}{*}{0513} & 94 & 64.9 & 186.9 & 169.9 & 24.3 & 3.0 & 8.8 & 6.9 & 10.0 & 6.9 & 91.5 & 124.6 & 14.3 & 13.9 & 12.2 \\
\hline & 95 & 73.2 & 223.6 & 214.3 & 23.8 & 3.1 & 10.8 & 7.8 & 11.6 & 39.7 & 93.9 & 125.2 & 82.3 & 10.6 & \\
\hline \multirow[t]{2}{*}{0514} & 94 & 67.3 & 170.8 & 154.6 & 21.9 & 3.0 & 8.6 & 7.5 & 9.8 & 6.0 & 73.1 & 107.2 & 15.0 & 13.7 & 11.0 \\
\hline & 95 & 82.3 & 198.4 & 188.4 & 23.3 & 3.1 & 9.3 & 7.7 & 10.2 & 56.8 & 76.3 & 104.2 & 129.0 & 11.9 & \\
\hline \multirow[t]{2}{*}{0515} & 94 & 79.6 & 214.5 & 200.7 & 24.1 & 3.0 & 9.8 & 6.0 & 10.3 & 12.4 & 70.3 & 99.4 & 25.9 & 11.6 & 11.7 \\
\hline & 95 & 90.1 & 224.0 & 213.9 & 24.5 & 3.1 & 9.9 & 5.8 & 10.1 & 72.0 & 73.8 & 98.9 & 158.6 & 11.1 & \\
\hline \multirow[t]{2}{*}{1054} & 94 & 91.1 & 191.2 & 167.3 & 23.7 & 3.0 & 9.3 & 11.7 & 9.2 & 4.8 & 83.2 & 116.0 & 9.9 & 13.9 & 15.0 \\
\hline & 95 & 60.8 & 184.2 & 176.0 & 22.8 & 3.1 & 9.3 & 11.3 & 9.7 & 25.8 & 91.6 & 113.5 & 52.8 & 12.7 & \\
\hline \multirow[t]{2}{*}{1058} & 94 & 71.8 & 196.9 & 174.2 & 27.9 & 3.0 & 9.3 & 11.3 & 9.2 & 3.2 & 79.6 & 110.6 & 6.4 & 15.7 & 12.6 \\
\hline & 95 & 76.3 & 209.2 & 199.1 & 26.1 & 3.2 & 9.6 & 11.6 & 9.6 & 65.4 & 86.3 & 112.7 & 125.6 & 12.8 & \\
\hline \multirow[t]{2}{*}{1061} & 94 & 71.2 & 211.0 & 188.5 & 27.1 & 3.0 & 9.1 & 12.0 & 9.1 & 3.0 & 79.9 & 108.5 & 5.8 & 14.0 & 14.5 \\
\hline & 95 & 85.5 & 239.1 & 229.4 & 27.2 & 3.1 & 10.2 & 11.5 & 10.5 & 59.1 & 83.6 & 106.6 & 109.5 & 11.6 & \\
\hline \multirow[t]{2}{*}{1071} & 94 & 76.9 & 193.5 & 167.7 & 24.1 & 3.0 & 10.4 & 14.6 & 9.3 & 5.7 & 74.3 & 108.1 & 12.1 & 13.8 & 12.9 \\
\hline & 95 & 86.1 & 196.6 & 187.6 & 23.0 & 3.2 & 10.8 & 12.2 & 10.1 & 45.8 & 76.5 & 100.0 & 103.8 & 11.8 & \\
\hline \multirow[t]{2}{*}{1091} & 94 & 71.8 & 196.5 & 174.8 & 27.6 & 3.0 & 9.2 & 12.5 & 9.0 & 3.8 & 89.6 & 120.6 & 7.0 & 15.4 & 10.4 \\
\hline & 95 & 84.5 & 214.3 & 206.5 & 26.9 & 3.2 & 9.6 & 11.8 & 9.4 & 103.8 & 85.3 & 111.9 & 198.4 & 12.7 & \\
\hline \multicolumn{16}{|l|}{ E. hispanicus } \\
\hline \multirow[t]{2}{*}{0475} & 94 & 94.0 & 238.5 & 221.1 & 17.8 & 3.3 & 12.7 & 9.5 & 12.8 & 8.2 & 59.9 & 94.8 & 25.3 & 7.7 & 15.7 \\
\hline & 95 & 88.8 & 218.5 & 203.3 & 16.6 & 3.8 & 15.7 & 10.1 & 13.1 & 25.9 & 62.4 & 92.6 & 84.9 & 7.7 & \\
\hline \multirow[t]{2}{*}{0485} & 94 & 85.0 & 212.5 & 194.3 & 18.4 & 3.3 & 12.6 & 11.2 & 12.6 & 10.4 & 58.8 & 94.3 & 30.3 & 9.0 & 20.4 \\
\hline & 95 & 80.3 & 177.6 & 160.1 & 14.7 & 3.9 & 14.7 & 11.0 & 13.3 & 39.7 & 54.5 & 86.9 & 141.0 & 8.6 & \\
\hline \multirow[t]{2}{*}{0488} & 94 & 97.8 & 231.2 & 217.1 & 18.9 & 3.1 & 13.5 & 9.2 & 13.4 & 10.5 & 54.6 & 92.1 & 29.3 & 8.3 & 11.1 \\
\hline & 95 & 89.5 & 212.1 & 194.2 & 18.1 & 4.1 & 15.7 & 10.5 & 13.3 & 51.2 & 54.2 & 86.6 & 151.3 & 8.8 & \\
\hline \multirow[t]{2}{*}{0489} & 94 & 81.7 & 213.0 & 193.9 & 17.8 & 3.0 & 11.4 & 9.1 & 11.9 & 5.0 & 73.0 & 104.5 & 15.8 & 8.7 & 9.5 \\
\hline & 95 & 89.1 & 225.2 & 205.1 & 17.7 & 3.7 & 16.2 & 11.3 & 12.4 & 19.0 & 69.4 & 96.8 & 58.9 & 8.1 & \\
\hline \multirow[t]{2}{*}{0523} & 94 & 89.0 & 200.8 & 184.0 & 13.0 & 3.1 & 11.6 & 8.0 & 12.0 & 10.1 & 49.2 & 87.3 & 40.1 & 6.6 & 12.2 \\
\hline & 95 & 84.5 & 184.9 & 167.9 & 12.7 & 3.8 & 13.9 & 9.2 & 12.1 & 37.6 & 50.2 & 83.9 & 155.6 & 7.0 & \\
\hline
\end{tabular}

\section{Discussion}

The clear separation between the genera Elymus and Thinopyrum observed in the dendrogram of Figure 1 is in agreement with the genomic classification of Löve [9], but not with the morphological classification of Flora Europaea [10]. Flora Europaea considers both genera as Elymus. At the species level it was observed that the separation between the two species of Thinopyrum was small- er than that between the two representatives of Elymus. The results suggest that the genomes of $E$. caninus and E. hispanicus are less related than those of $T$. junceun and $T$. junceiforme, which in fact are variations of the same E genome [17].

Elymus species had better germination rates, more spikelets per spike, higher spike density and a higher number of seeds than those of Thinopyrum. This might be related to the different reproductive systems of the two genera. In Elymus species there is only sexual reproduction, while in 
Table VII. Coefficients of variation (\%) for quantitative traits for two years and four species.

\begin{tabular}{|c|c|c|c|c|c|c|c|c|}
\hline \multirow[t]{2}{*}{ Trait } & \multicolumn{2}{|c|}{ T. junceum } & \multicolumn{2}{|c|}{ T. junceiforme } & \multicolumn{2}{|c|}{ E. caninus } & \multicolumn{2}{|c|}{ E. hispanicus } \\
\hline & 94 & 95 & 94 & 95 & 94 & 95 & 94 & 95 \\
\hline Flag leaf area $\left(\mathrm{cm}^{2}\right)$ & 45.5 & & 44.6 & & 36.3 & & 40.9 & \\
\hline Plant height $(\mathrm{cm})$ & 20.2 & 25.1 & 14.6 & 23.6 & 16.5 & 20.6 & 10.1 & 10.6 \\
\hline Spike length (mm) & 27.2 & 30.8 & 16.5 & 25 & 16.1 & 16.9 & 13.4 & 15.2 \\
\hline Rachis length (mm) & 30 & 33.8 & 19.2 & 30.1 & 18.4 & 17.5 & 15.1 & 17 \\
\hline $\begin{array}{l}\text { Number of spikelets } \\
\text { per spike }\end{array}$ & 20.7 & 20.1 & 18.3 & 29.2 & 16.8 & 16.6 & 18.4 & 19.6 \\
\hline Spikelet width $(\mathrm{mm})$ & 17.5 & 19.8 & 18.1 & 15.7 & 2 & 10.5 & 11.5 & 13.3 \\
\hline Glume length (mm) & 13.9 & 15.2 & 12 & 12.9 & 13.9 & 11.7 & 16.5 & 11.8 \\
\hline Lemma length (mm) & 12 & 10.9 & 10.7 & 9.4 & 12.7 & 11.2 & 12.5 & 9.9 \\
\hline Awn length $(\mathrm{mm})$ & & & & & 37.1 & 32.6 & 34.4 & 18.2 \\
\hline $\begin{array}{l}\text { Number of kernels } \\
\text { per spike }\end{array}$ & 92.3 & 56.6 & 124.1 & 101.2 & 129.1 & 70.9 & 77.6 & 55.6 \\
\hline $\begin{array}{l}\text { Heading date, } \\
\text { days after } 3 / 31\end{array}$ & 9.8 & 11.0 & 10.5 & 9.2 & 13.6 & 15.1 & 18.1 & 18.1 \\
\hline $\begin{array}{l}\text { Maturity date, } \\
\text { days after } 3 / 31\end{array}$ & 5.6 & 5.5 & 5.1 & 12.2 & 10.2 & 11.7 & 9.6 & 8.1 \\
\hline Mean* & 26.8 & 22.9 & 26.7 & 26.8 & 26.0 & 20.3 & 22.2 & 17.9 \\
\hline
\end{tabular}

* Without awn length.

Table VIII. F-test values and significance for two years and four species.

\begin{tabular}{|c|c|c|c|c|c|c|c|c|}
\hline \multirow[t]{2}{*}{ Trait } & \multicolumn{2}{|c|}{ T. junceum } & \multicolumn{2}{|c|}{ T. junceiforme } & \multicolumn{2}{|c|}{ E. caninus } & \multicolumn{2}{|c|}{ E. hispanicus } \\
\hline & 94 & 95 & 94 & 95 & 94 & 95 & 94 & 95 \\
\hline Flag leaf area $\left(\mathrm{cm}^{2}\right)$ & $7.80 * *$ & & $4.11 * *$ & & $3.70 * *$ & & $27.08 * *$ & \\
\hline Plant height $(\mathrm{cm})$ & $12.79 * *$ & $3.90 * *$ & $13.26 * *$ & $8.04 *$ & $12.44 * *$ & $10.75^{* * *}$ & $22.37 * *$ & $5.78 * *$ \\
\hline Spike length (mm) & $22.82 * *$ & $22.03 * *$ & $0.32 \mathrm{NS}$ & $0.18 \mathrm{NS}$ & $9.40^{* *}$ & $7.36^{* *}$ & $10.15 * *$ & $19.17 * *$ \\
\hline Rachis length (mm) & $24.91 * *$ & $22.02 * *$ & $1.24 \mathrm{NS}$ & $0.00 \mathrm{NS}$ & $11.92 * *$ & $7.24 * *$ & $10.43 *$ & $17.21 * *$ \\
\hline $\begin{array}{l}\text { Number of spikelets } \\
\text { per spike }\end{array}$ & $12.47 * *$ & $6.78 * *$ & $0.28 \mathrm{NS}$ & $1.12 \mathrm{NS}$ & $12.56^{* *}$ & $10.93 * *$ & $31.49 * *$ & $24.56^{* *}$ \\
\hline Spikelet width (mm) & $3.57 * *$ & $3.93 * *$ & $0.13 \mathrm{NS}$ & $23.05 * *$ & $0.96 \mathrm{NS}$ & $1.22 \mathrm{NS}$ & $4.90 * *$ & $2.90^{*}$ \\
\hline Glume length (mm) & $5.85 * *$ & $5.55 * *$ & $0.39 \mathrm{NS}$ & $0.98 \mathrm{NS}$ & $5.33 * *$ & $7.14 * *$ & $5.44 * *$ & $9.42 * *$ \\
\hline Awn length (mm) & & & & & $27.67 * *$ & $21.22 * *$ & $4.01 * *$ & $5.85 * *$ \\
\hline Lemma length (mm) & $6.29 * *$ & $3.98 * *$ & $0.66 \mathrm{NS}$ & $0.59 \mathrm{NS}$ & $12.87 * *$ & $9.93 * *$ & $4.46^{* *}$ & $6.18 * *$ \\
\hline $\begin{array}{l}\text { Heading date, } \\
\text { days after } 3 / 31\end{array}$ & $35.25^{* *}$ & $27.03^{* *}$ & $2.43 \mathrm{NS}$ & $1.13 \mathrm{NS}$ & $32.26 * *$ & $16.10^{* *}$ & $32.83 * *$ & $23.02 * *$ \\
\hline $\begin{array}{l}\text { Maturity date, } \\
\text { days after } 3 / 31\end{array}$ & $31.29 * *$ & $16.00 * *$ & $0.02 \mathrm{NS}$ & $0.10 \mathrm{NS}$ & $38.37 * *$ & $23.80 * *$ & $17.23 * *$ & $21.39^{* *}$ \\
\hline
\end{tabular}

*, ** Means among populations in each species differ at $P=0.05$ and 0.01 respectively. 


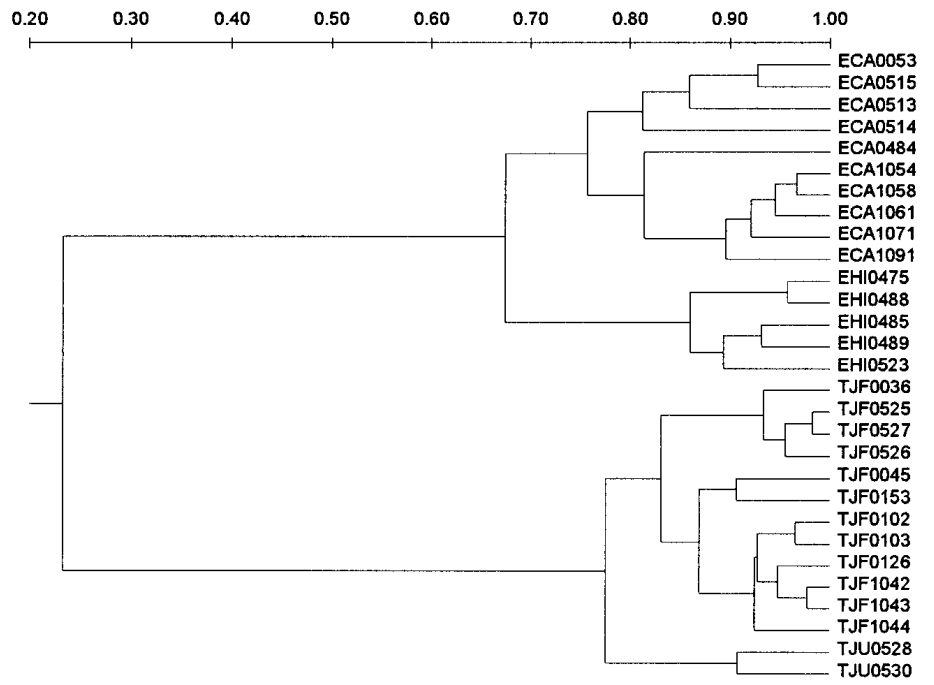

Figure 1. Dendrogram obtained for T. junceum (TJU), T. junceiforme (TJF), E. caninus (ECA), and E. hispanicus (EHI) by the UPGMA method.

Thinopyrum species there is both sexual and asexual reproduction (rhizomatous).

The means of characteristics related to spike fertility increased in all species during the second year. This was probably due to the different climatological conditions. The first year of study was warmer and drier than the second, and this could have affected seed formation. Characteristics related to vigour increased the second year only for the species E. caninus. This could be related to the habitat - there is greater humidity and the temperature is lower where this species grows.

Using analysis of variance to compare populations, it was observed that, with the exception of $T$. junceiforme (only two populations were analysed), inter-population variability was greater than intrapopulation variability in all species. This is typical of autogamous populations [6].

The results for the qualitative traits were in accordance with those for the quantitative traits which consider E. hispanicus to be the less variable species. This could be due to the fact that the populations of E. hispanicus selected for this study were found within the same geographical area, in the south of the Iberian Peninsula, the only ecological habitat for this species in Spain.
Population 1044 of $T$. junceum, which grows in the northernmost area from which the studied plants were collected, was also that with the longest cycle and the biggest spikes. Population 527 , which grows in the southernmost area, was the shortest and showed the lowest mean number of days to heading and maturity. In the dendrogram of Figure 1, groups of populations appeared to be related to latitude. The first subgroup included the southern populations from AlmerÌa (0036), Málaga (0527) and Granada (0525 and 0527). A second subgroup included the northern populations between Barcelona (1044) and Murcia (0045). Groups within E. caninus did not seem to be influenced by latitude. Table I shows that variations between populations of $T$. junceum were only slight with respect to altitude (these plants grow in coastal areas), but were greater with respect to latitude. In populations of E. caninus, there were variations with respect to both parameters.

The collection of wild populations studied showed a high level of morphological and agronomical variability which may be useful in future breeding programmes.

Acknowledgements. The authors thank the I.N.I.A. (Instituto Nacional de Investigación y Tecnología Agraria y Alimentaria) of Spain for their financial 
support (Plan Sectorial M.A.P.A. Grant Number SC93176-C2), and Steven C. Meschia and Adrian Burton for helpful linguistic assistance.

\section{References}

[1] Asay K.H., Dewey D.R., Horton W.H., Jensen K.B., Currie P.O., Chatterton N.J., Hansen II W.T., Carlson J.R., Registration of "Newhy" RS hybrid wheatgrass, Crop Sci. 31 (1991) 1384-1385.

[2] Bothmer R. von, Salomon B., Triticeae: a tribe for food, feed, and fun, in: Proceedings of the 2nd International Triticeae Symposium, Logan, Utah, 1994, pp. 1-12.

[3] Dewey D.R., The genomic system of classification as a guide to intergeneric hybridization with the perennial Triticeae, in: Gustafson J.P. (Ed.), Gene Manipulation in Plant Improvement, Proc. 16th Stadler Genet. Symp., New York, 1984, pp. 209-279.

[4] Duvick D.N., Genetic diversity in major farm crops on the farm and in reserve, Econ. Bot. 38 (1984) 161-178.

[5] Gabel M.L., A biosystematic study of the genus Elymus (Gramineae: Triticeae) in Iowa, Proc. Iowa Acad. Sci. 91 (1984) 140-146.

[6] Hamrick J.L., Linhart Y.B., Mitton J.B., Relationships between life history characteristics and electrophoretically detectable genetic variation in plants, Ann. Rev. Ecol. Syst. 10 (1979) 173-200.

[7] Hawkes J.G., Crop genetic resources. Field collection manual for seed crops, root and tuber crops, tree fruit crops and related wild species, International Board for Plant Genetic Resources (I.B.P.G.R.) and the European Association for Research on Plant Breeding (EUCARPIA), 1980.

[8] Jensen K.B., Zhang Y.F., Dewey D.R., Mode of pollination of perennial species of the Triticeae in relation to genomically defined genera, Can. J. Plant Sci. 70 (1990) 215-225.

[9] Löve A., Conspectus of the Triticeae, Feddes Repert. 95 (1984) 425-521.

[10] Melderis A., Elymus, in: Tutin T.G. et al. (Eds.), Flora Europaea, Cambridge University Press, Cambridge, 1980, Vol. 5, pp. 192-198.

[11] Michener C.D., Sokal R.R., A quantitative approach to a problem in classification, Evolution 11 (1957) 130.

[12] Rohlf J.F., NTSYS. PC: numerical taxonomy and multivariate analysis system for the IBM PC microcomputer (and compatibles). Setavek, Applied Biostatistics, INC, N.Y., 1987.

[13] Salomon B., Lu B.-R., Genomic groups, morphology, and sectional delimitation in Eurasian Elymus (Poaceae, Triticeae), Plant Syst. Evol. 180 (1992) 21-13.

[14] Sharma H.C., Gill B.S., Current status of wide hybridization in wheat, Euphytica 32 (1983) 17-31.

[15] Soler C., Ruíz-Fernández J., Monte J.V, de Bustos A., Jouve N., The assessment of variability in Spanish populations of wild relatives of cereals, Bocconea 7 (1997) 107-119.

[16] Talavera S., Elymus hispanicus (Boiss.) Talavera, comb. nova, Lagascalia 14 (1986) 170-171.

[17] Wang R.R-C., Bothmer R. von, Dvorák J., Fedak G., Linde-Laursen I., Genome Symbols in the Triticeae (Poaceae), in: Proceedings of the 2nd International Triticeae Symposium, Logan, Utah, 1994, pp. 29-34.

[18] Wang R.R-C., Dong Y., Zhou R., Resistance to powdery mildew and barley yellow dwarf in perennial Triticeae species, Genet. Res. Crop Evol. 40 (1993) 171-176.

[19] Zhong G.-Y., Qualset C.O., Quantitative genetic diversity and conservation strategies for an allogamous annual species. Dasypyrum villosum (L.) Candargy (Poaceae), Theor. Appl. Genet. 91 (1995) 